\title{
The value capture potential of the Lisbon subway
}

\author{
Luis Miguel Garrido Martínez \\ Instituto Superior Técnico, Lisbon ${ }^{\text {a }}$
}

\author{
José Manuel Viegas \\ Instituto Superior Técnico, Lisbon ${ }^{\text {b }}$
}

\begin{abstract}
This paper tries to build on traditional value capture measures, to estimate the potential of some of these mechanisms for the Lisbon subway by examining their ability to mitigate the system's operation and development costs. The study focus is on the municipality of Lisbon where this system mainly operates. This research uses spatial hedonic pricing models of the real estate of the region, calibrated on previous stages of the study, to assess the extent to which transportation infrastructure is currently capitalized into the real estate market. The paper uses a Monte Carlo simulation procedure to estimate a synthetic population of residential and non-residential properties that matches the census blocks statistics, measuring the subway valuation for each synthetic property and aggregating the results for the whole municipality. This potential value capture estimate is then used to estimate an annual tax that could be charged under different value capture measure configurations (i.e., land value tax, special assessment). The results suggest that there is significant potential for the use of this instrument to finance the subway infrastructure.
\end{abstract}

Keywords: Value capture; Transport financing; Fiscal simulation; Real estate hedonic price models; Subways; Lisbon

\section{Introduction}

Most of the cities across the world are currently facing challenges in financing public transport. For several decades now, Urban Public Transport (UPT) has been unable to collect enough revenues from clients to cover its production costs. The fact that public transit is seen as an indispensable service in all medium and large cities, accompanied by the operating constraints and the multiple (and sometimes conflicting) objectives under which it performs, have largely prevented radical political moves to force its cost coverage to be more in line with the normal market economy (Viegas 2005).

Parallel with these financial difficulties, the service provided by UPT, even with younger fleets and more comfortable vehicles, has not been attractive enough to resist the higher availability and comfort provided by the private car. Thus the long term market share of UPT has been declining in all cities around the world, with only a few recent short term exceptions. The financing problem of UPT, partly explained by this loss of competitiveness and patronage, is accompanied by the problem of generally low quality and sustainability (Viegas 2005).

${ }^{a}$ Civil Engineering Department. martinez@civil.ist.utl.pt

b Civil Engineering Department. viegas@civil.ist.utl.pt
Furthermore, accessibility to desired destinations tends to play a major role in location decisions of activities and residential location, which raises land value in highly accessible locations. The monetary value of this accessibility is reflected in the value of a home or a business, in addition to the value of other features such as the specific physical attributes of the building and neighborhood characteristics (Lari et al. 2009).

Value capture then arises as the process whereby a funding agency (i.e., the city, the region, or the state) attempts to recover a share of the value added to property resulting from any infrastructure development (Hass-Klau 2006).

This paper examines the value capture potential of Lisbon's subway by testing several different mechanisms, and looks at its integration with the current fiscal system in order to develop a new financing framework for the system operation and infrastructure development within the municipality of Lisbon.

This study uses a Monte Carlo simulation procedure in order to estimate a synthetic market composition of the residential, retail, and office sectors from the aggregated statistical data available at city block level, leading to an estimate of the value capture potential of the subway in the Lisbon municipality.

The potential value capture estimate is then analyzed in order to extract an annual tax for dwellings and commercial ar-

Copyright 2012 Luis Miguel Garrido Martínez and José Manuel Viegas.

Licensed under the Creative Commons Attribution - NonCommercial License 3.0. 
eas that could be charged as different types of annual taxes to property owners. This annual potential revenue is compared with the annual financial cost of the subway infrastructure operation and development, allowing a first insight on the value capture impact on the financial infrastructure development. Finally, the estimated tax is compared with the existing municipal Land Value Tax (LVT) in order to analyze the viability of its integration with the current fiscal system.

\section{A brief review of current practice in financing transport infrastructure}

The funding of transport projects in most developed countries has become increasingly complex since the Second World War. In the early post-war period transport infrastructure projects were primarily funded through national government, with contributions sought by users either directly or indirectly (e.g., fares, petrol taxes, vehicle registration duty, etc.). The focus of such investment was more inclined to road and airport schemes, rather than railways (which had a highly used and well developed infrastructure in good alignment with stable vehicle technology) and non-mechanized forms of transport (GVA Grimley 2004).

Figure 1 presents the evolution of the expenditure of the public transport sector in the United States. The figure shows strong growth in the total expenditures of the transport sector since 1970, while the commercial revenues, including the charged fares, have stalled. This fact has generated a parallel growth in subsidies paid by public funds, substantially increasing public obligation to support the development, operation, and maintenance of transport infrastructures. A similar trend has been observed in Europe (see Table 1) and other developed countries, increasing the need of introducing alternative sources of funding, often closer to the beneficiary-pays principle.

From the viewpoint of the burden theory of financial resources, the question of who should pay is of deep concern, and is related to the most basic questions of how to assess the role and purpose of transport improvements. If the paradigm is that improvements will only result in increased user convenience, then users should bear the cost. However, transportation systems are not only part of the social infrastructure for all industries and activities, but also have a social welfare dimension in ensuring freedom of movement for all. In addition, there may be external effects such as capital gains accruing to local land owners. Finally, the question of financing is complicated by such issues as the external costs of environmental
Table 1: Summary of the percentage of revenue of European public transport operators received from subsidies or grants.

\begin{tabular}{lcc}
\hline Country & $\begin{array}{c}\text { Number } \\
\text { of cities }\end{array}$ & $\begin{array}{c}\text { Average percentage } \\
\text { of revenue from } \\
\text { subsidies or grants }\end{array}$ \\
\hline Austria & 3 & 32 \\
Belgium & 3 & 61 \\
Croatia & 1 & 23 \\
Czech & 3 & 65 \\
Denmark & 1 & 36 \\
Finland & 1 & 51 \\
France & 7 & 44 \\
Germany & 21 & 47 \\
Greece & 1 & 22 \\
Hungary & 1 & 28 \\
Italy & 4 & 7 \\
Netherlands & 2 & 67 \\
Norway & 1 & 3 \\
Poland & 4 & 47 \\
Portugal & 2 & 2 \\
Romania & 2 & 59 \\
Sweden & 1 & 52 \\
Switzerland & 3 & 35 \\
Yugoslavia & 1 & 41 \\
\hline
\end{tabular}

Source: Reynolds-Feighan et al. (2000).

impact and the need to distribute the burden across generations (Nakagawa and Matsunaka 1997).

Over the last 20 years there has been an increasing shift towards deregulation of public transport, allied with encouragement of private sector involvement in transport project funding, and even design, construction, and operation (Vivier 1999; Worsey 2005). The main forms of direct private sector involvement in terms of funding transport schemes has been through Private Finance Initiative (PFI)/Public-private partnership (PPP) contracts, Design, Build, Finance, and Operate (DBFO) contracts, and direct equity funding. In addition, European governments can apply for grants from the European Union to promote this type of financing scheme, as well as access other funding streams set up by the European Commission (Faber 2000).

The current pressure over public investment in transportation infrastructure led governments toward a mixed use of these methods, and the consideration of various alternative sources of funding to supplement government financing for transport through the annual government budgets, or even to replace it (Berry and Sims 1999; Godier 2002; Simon 1999; Ubbels and Nijkamp 2002). 
Figure 1: United States public transport expenditures, subsidies and passenger usage since the 1970s. Source: (Wendell Cox Consultancy 2006).

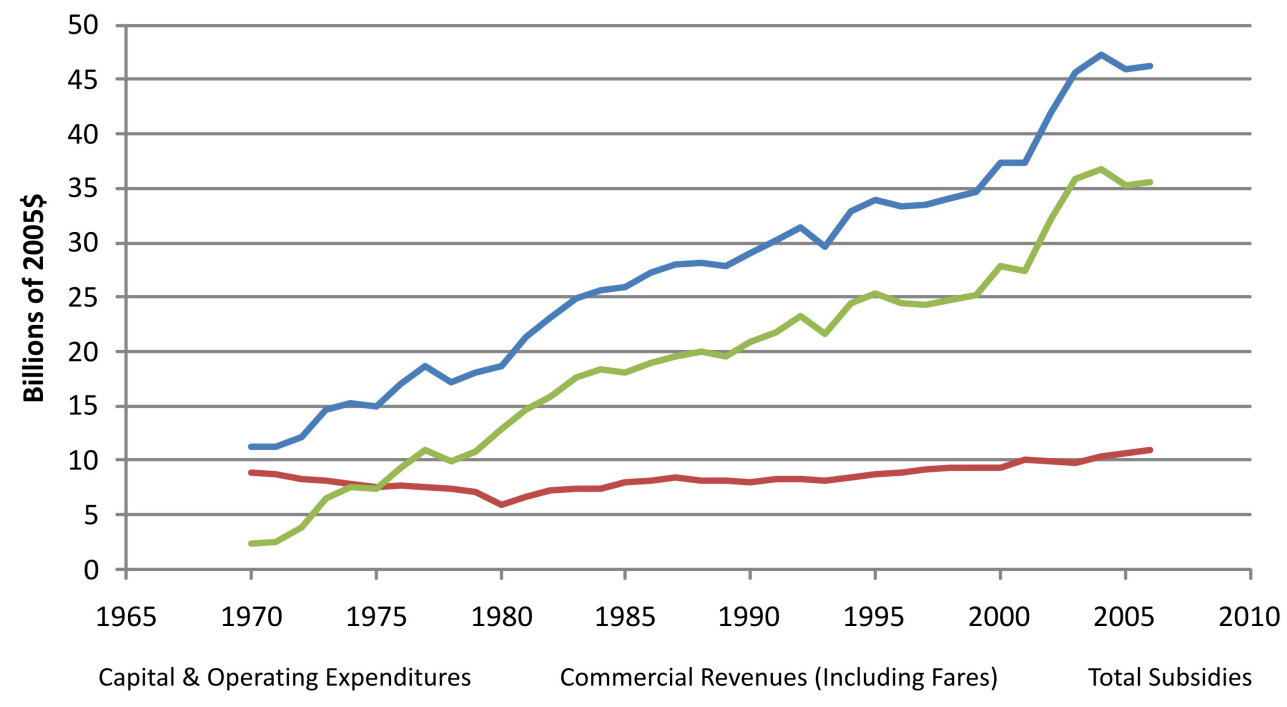

In this context, alternative public transport funding methods have been introduced in some countries. Some of the alternative methods are focused on the implementation of land value capture mechanisms which try to recoup part of the value added by transportation improvements that often produce profit windfalls for land and property owners.

To date, most studies of value capture financing for public transport have focused on cities in developed countries, where low density development and automobile dependency predominate. Studies have begun to emerge from developing countries, where denser cities and a more even modal split can be found, like Jakarta (Cervero and Susantono 1999), Bogota (Rodriguez and Targa 2004), Uruguay (Prest 1969), and studies for several developing countries at once (Nakagawa and Matsunaka 1997; Tsukada and Kuranami 1990). Some of these authors have noted that while progressive legislation may exist, the practical means of capturing site values for public transport projects is hampered by inadequate land registration records and lagging assessments.

Table 2 presents a summary of value capture techniques that have been applied around the world, where the main advantages and disadvantages of each mechanism are analyzed based on a RICS report about London's transport funding (GVA Grimley 2004), among other studies.

\section{Methodology}

This study presents several models in order to estimate the current value capture potential of the subway system and to determine how this value capture potential could be linked to the current land value tax fiscal system.

Two different types of synthetic properties simulation models were developed to estimate the attributes of the existing real estate stock, one based on hedonic prices and another based on land value tax legislation. The former estimates the market value of that stock and the value capture potential of the subway, whereas the latter estimates its asset value used to determine the annual land value tax.

These models will allow estimation of the annual value capture charge for the different mechanisms tested, and of the additional tax burden that would be generated by their application to property owners.

The value capture policies tested in the study were:

1. a Special Assessment (SA) tax, which would be implemented in a defined impact area close to the subway stations;

2. the integration of a value capture tax with the current land value tax. 
Table 2: Innovative funding methods for transport infrastructure.

\begin{tabular}{|c|c|c|c|c|}
\hline Funding Method & Focus & Funding Source & Advantages & Disadvantages \\
\hline $\begin{array}{l}\text { Land Value Taxation } \\
\text { (LVT)/Site Value } \\
\text { Rating }\end{array}$ & Beneficiary pays & $\begin{array}{l}\text { Land/Property } \\
\text { Property-related } \\
\text { taxes }\end{array}$ & $\begin{array}{l}\text { Encourages appropriate } \\
\text { development. Landowners } \\
\text { who see a fall in value are } \\
\text { compensated. }\end{array}$ & $\begin{array}{l}\text { Regular valuations required. } \\
\text { Initial data collection. } \\
\text { Requires primary legislation. }\end{array}$ \\
\hline
\end{tabular}

Case studies: Most general type of value capture policy applied widely around the world for general public goods provision (variations: split rate property tax).

\begin{tabular}{|c|c|c|c|c|}
\hline $\begin{array}{l}\text { Tax Incremental } \\
\text { Financing } \\
\text { (TIF)/LRTP }\end{array}$ & $\begin{array}{l}\text { Development- } \\
\text { based, Beneficiary } \\
\text { pays }\end{array}$ & $\begin{array}{l}\text { Land/Property } \\
\text { Property-related } \\
\text { taxes }\end{array}$ & $\begin{array}{l}\text { Defers payment from } \\
\text { business. Can stimulate new } \\
\text { development. Does not } \\
\text { require primary legislation. }\end{array}$ & $\begin{array}{l}\text { Cannot guarantee } \\
\text { development. Funding can } \\
\text { also be slow to come forward. }\end{array}$ \\
\hline
\end{tabular}

Case studies: Widespread adoption in many US states. In Chicago, TIF districts have been established to support the construction of subway/elevated stations near the CBD (McGreal et al. 2002). Portland, Oregon has also promoted TIF districts to support streetcar and light rail development (Dueker and Bianco 1999). Adoption in other cities for urban regeneration processes not related to transport (e.g. Dublin) (McGreal et al. 2002).

\begin{tabular}{|c|c|c|c|c|}
\hline $\begin{array}{l}\text { Special Assessments } \\
\text { (SA)/Business } \\
\text { Improvement } \\
\text { Districts }\end{array}$ & $\begin{array}{l}\text { Development- } \\
\text { based, Beneficiary } \\
\text { pays }\end{array}$ & $\begin{array}{l}\text { Land/Property } \\
\text { Property-related } \\
\text { taxes }\end{array}$ & $\begin{array}{l}\text { Does not require primary } \\
\text { legislation. Can increase } \\
\text { public-private cooperation. }\end{array}$ & $\begin{array}{l}\text { Difficult boundary definition } \\
\text { and business inclusion. } \\
\text { Payment levels can be } \\
\text { difficult to structure. Seen as } \\
\text { an extra tax. }\end{array}$ \\
\hline
\end{tabular}

Case studies: Created in the United States and Canada (Hass-Klau 2006). In Los Angeles a variation of this tax known as "Special Assessment Districts" was introduced. This tax feeds a share of the increase in property values associated with a newly established rail line (typically on sites within $400-800 \mathrm{~m}$ of the stations) back into funding the public transport system (Doherty 2004).

\begin{tabular}{|c|c|c|c|c|}
\hline $\begin{array}{l}\text { Transportation Utility } \\
\text { Fees }\end{array}$ & Beneficiary pays & $\begin{array}{l}\text { Transportation is } \\
\text { seen as a } \\
\text { utility/Transport- } \\
\text { demand-related }\end{array}$ & $\begin{array}{l}\text { Potentially efficient to } \\
\text { finance local transport by } \\
\text { shifting cost burden to } \\
\text { residents and commercial } \\
\text { and industrial properties. } \\
\text { Stable source of funding. }\end{array}$ & $\begin{array}{l}\text { Regular valuations required } \\
\text { based on trip generation rates } \\
\text { for different properties (i.e. } \\
\text { Trip Generation Handbook). } \\
\text { Initial data collection. } \\
\text { Requires primary legislation. }\end{array}$ \\
\hline
\end{tabular}

Case studies: US examples in Colorado, Oregon, and Texas (Lari et al. 2009).

\begin{tabular}{llll}
\hline & Beneficiary pays $\quad$ One-time charges & $\begin{array}{l}\text { Improved efficiency in } \\
\text { resource allocation in local } \\
\text { gevernments. }\end{array}$ & $\begin{array}{l}\text { Narrow revenue capabilities. } \\
\text { Problems with ability to pay } \\
\text { in low-income locations. }\end{array}$ \\
Fees & & $\begin{array}{l}\text { Case studies: There are several examples throughout the United States, especially in fast growing areas such as } \\
\text { California, Florida and Texas (Doherty 2004). }\end{array}$ \\
\hline
\end{tabular}


Table 2: Innovative funding methods for transport infrastructure (Continued).

\begin{tabular}{lllll}
\hline Funding Method & Focus & Funding Source & Advantages & Disadvantages \\
\hline & Beneficiary pays & $\begin{array}{l}\text { Land/Property } \\
\text { Development land } \\
\text { charges }\end{array}$ & $\begin{array}{l}\text { Seen as a "proactive" tool in } \\
\text { which those who are } \\
\text { prepared to invest see } \\
\text { increased opportunity to } \\
\text { obtain benefits. }\end{array}$ & $\begin{array}{l}\text { May only secure relatively } \\
\text { small levels of revenue. }\end{array}$ \\
& & & $\begin{array}{l}\text { Would require changes to } \\
\text { Local Plans/UDPs. }\end{array}$
\end{tabular}

Case studies: Applied in the spatially coincidental developments of transport facilities and private real estate development (Lari et al. 2009).

\begin{tabular}{lllll}
\hline Business Rate Levy $\quad$ Beneficary pays & $\begin{array}{l}\text { Land/Property } \\
\text { Property-related } \\
\text { taxes }\end{array}$ & $\begin{array}{l}\text { Difficult to avoid, and } \\
\text { business rating list is regularly } \\
\text { updated. Value changes are } \\
\text { self-adjusted changes. }\end{array}$ & $\begin{array}{l}\text { Tenants charged twice } \\
\text { effectively. Payers do not see } \\
\text { any direct benefit in land } \\
\text { values, unless an owner } \\
\text { occupier. }\end{array}$ \\
\end{tabular}

Case studies: Applied in London to fund Crossrail operations (Lari et al. 2009).

\begin{tabular}{lllll}
\hline Geneficiary pays & $\begin{array}{l}\text { Land/Property } \\
\text { Property-related } \\
\text { taxes }\end{array}$ & $\begin{array}{l}\text { Encourages development in } \\
\text { more sustainable locations. } \\
\text { The tax-service the } \\
\text { development link. }\end{array}$ & $\begin{array}{l}\text { May be difficult to define } \\
\text { "Greenfield" sites. May } \\
\text { encourage development } \\
\text { activity to other } \\
\text { areas/regions. Would require } \\
\text { legislation in some form. }\end{array}$ \\
& & &
\end{tabular}

Case studies: Several US cities have applied this tax to control urban sprawl (Whelan et al. 2003).

\begin{tabular}{|c|c|c|c|c|}
\hline $\begin{array}{l}\text { Betterment Levy/ } \\
\text { Freehold Levy }\end{array}$ & Beneficiary pays & $\begin{array}{l}\text { Land/Property } \\
\text { Development land } \\
\text { charges }\end{array}$ & $\begin{array}{l}\text { Charges based on sale price } \\
\text { are easy to collect. Concept } \\
\text { simple to understand. }\end{array}$ & $\begin{array}{l}\text { Would penalize those who } \\
\text { lost value as a result of the } \\
\text { scheme. Would require } \\
\text { legislation. }\end{array}$ \\
\hline
\end{tabular}

Case studies: A levy on freehold property in a specific area. The levy is applied to the uplift in property values as a one-off charge. Applied in UK cities (GVA Grimley 2004; Lari et al. 2009).

\begin{tabular}{|c|c|c|c|c|}
\hline \multirow[t]{2}{*}{ Planning Gain/Tariffs } & Beneficiary pays & $\begin{array}{l}\text { Land/Property } \\
\text { Development land } \\
\text { charges }\end{array}$ & $\begin{array}{l}\text { Difficult to avoid as } \\
\text { development requires } \\
\text { planning consent. Relatively } \\
\text { straightforward and } \\
\text { understood. }\end{array}$ & $\begin{array}{l}\text { Section } 106 \text { agreements } \\
\text { would happen anyway. } \\
\text { Restricting use of funds to } \\
\text { transport schemes. }\end{array}$ \\
\hline & $\begin{array}{l}\text { Case studies: Th } \\
\text { to pay infrastruc } \\
\text { Section } 106 \text { in th }\end{array}$ & $\begin{array}{l}\text { hanism was introdu } \\
\text { sts generated by th } \\
\text { and the Section } 94 \mathrm{i}\end{array}$ & $\begin{array}{l}\text { due to the lack of funds in Ge } \\
\text { signation of urban land use ( } \\
\text { ustralia (Glaister and Graham }\end{array}$ & $\begin{array}{l}\text { an cities at the end of the } 1980 \text { s } \\
\text { old 2004). Other examples are } \\
\text { 005; Hass-Klau et al. 2004). }\end{array}$ \\
\hline
\end{tabular}




\section{Market value estimation model}

\subsection{Model data}

The synthetic properties model developed to assess value capture potential is based on spatial hedonic pricing models developed and calibrated in previous stages of our research. The variables required for each property are classified into three types: structural attributes of the properties (e.g., number of bedrooms, age, and existence of off-street parking facilities inside the property); neighborhood attributes, which include some indicators that characterize the vicinity of the property and measure their influence in the property price (i.e., education level indicator Educational Index or land use mixture indicator Entropy Index); and accessibility attributes that measure the influence of proximity to different types of transport infrastructure on property prices, including:

- proximity to subway stations, measured by a decreasing impedance function, using as argument walking distance to the two closest subway lines $2 M$ Access, and to the closest subway line $1 M$ Access;

- proximity to different levels of the road network, measured by a decreasing continuous impedance function, using as argument the Euclidean distance to the closest node of the three main levels of urban road hierarchy: road hierarchy level 1 (motorways) Network1, road hierarchy level 2 (urban ring roads and radial network) Network2, and road hierarchy level 3 (urban distribution network) Network3;

- proximity to commuter rail stations, measured also by a decreasing continuous impedance function, using as argument the walking access time to the closest stations of the commuter lines of Sintra (Sintra) and Cascais (Cascais).

These models use a semi-logarithmic specification with a spatial lag term as presented in Equation 1. The specification of the attributes of the models and their resulting coefficients are presented in Table 3.

$$
\begin{aligned}
& \ln \left(P_{i}\right)=\rho W_{\ln \left(P_{i}\right)}+\beta_{0}+\beta_{1}^{\prime} X_{i 1} \\
& \quad+\beta_{2}^{\prime} X_{i 2}+\cdots+\beta_{n}^{\prime} X_{i n}+\varepsilon_{i}, \quad \varepsilon \sim N\left(o, \sigma^{2} I\right)
\end{aligned}
$$

The data used to calibrate this model were obtained from an online realtor, the dependent variable being the advertised price at which the owner or realtor is offering the property.
This can be a limitation to the model because the dependent variable is not directly linked to an equilibrium price, where supply and demand have cleared the transaction (Rodríguez and Mojica 2007). Other studies that relate public transport accessibility to residential property or land values also have relied on asking prices (Benjamin and Sirmans 1996; Cheshire and Sheppard 2003; Du and Mulley 2007; Henneberry 1998; Rodriguez and Targa 2004; Rodríguez and Mojica 2007). We had no access to the transaction price, but we also see no reason why the discrepancy between the asking price and the transaction price should be related to location in general, or to proximity to a subway station in particular.

The development of the synthetic properties model required a comprehensive data collection process, including:

1. Census data on building and dwelling characteristics at city census block level for the characterization of the residential market. The census data allowed the definition of statistical distributions for the different structural property attributes of dwellings, and at the same time, controlled the total number of properties that exist at each census block.

2. Land use data on activities (offices, retail, and warehouses) for the Lisbon municipality, collected from the Portuguese Yellow Pages (http://www.pai.pt). This database contains all businesses that have been assigned fixed (landline) telephone numbers, which might exclude some activities that rely only on mobile phone services. Nevertheless, this sample was used to characterize the retail, office, and warehouse market due to a lack of better data.

3. A real estate cross-sectional database of 2007 from an online realtor's database (Imokapa Vector) for Lisbon, Portugal. This database presents the asking price of residential properties for sale during February 2007 with a total of 8742 complete records, and 1165 complete records for non residential properties, including retail, office, and warehouse properties. The real estate data contained information on their asking price, structural attributes, and address.

The neighborhood properties and the local accessibility attributes for residential and non-residential properties were computed considering as reference the centroid of each census block (normally smaller than $1 \mathrm{ha}$ ), as well as the spatial lag term, considering the real estate data available for Lisbon city, with an influence area threshold of $500 \mathrm{~m}$. 
Table 3: Summary of the hedonic price models used for property value estimation.

\begin{tabular}{|c|c|c|c|c|c|}
\hline \multicolumn{3}{|c|}{ Residential model (Martínez and Viegas 2009) } & \multicolumn{3}{|c|}{ Retail \& office model (Martínez 2010) } \\
\hline Variables & Coef. & Std. Error & Variables & Coef. & Std. Error \\
\hline SP_LAG_LOGPRICE & $0.3561^{* * *}$ & 0.0085 & SP_LAG_LOGPRICE & $0.0394^{* * *}$ & 0.0088 \\
\hline Constant & $6.9089^{* * *}$ & 0.0999 & Constant & $10.264^{* * *}$ & 0.1143 \\
\hline \multicolumn{6}{|c|}{ Structural attributes } \\
\hline Bedrooms & $0.0427^{* * *}$ & 0.003 & Store & $0.4147^{* * *}$ & 0.0446 \\
\hline House & $0.1685^{* * *}$ & 0.0154 & Office & $0.3892^{* * *}$ & 0.053 \\
\hline Floor & $0.0155^{* * *}$ & 0.0009 & Floor & $0.0227^{* *}$ & 0.0108 \\
\hline \multirow[t]{3}{*}{ Area } & $0.0064^{* * *}$ & 0.0001 & Areal & $0.0079^{* * *}$ & 0.0002 \\
\hline & & & Area2 & $0.0018^{* * *}$ & 0.0001 \\
\hline & & & Area3 & $0.0005^{* * *}$ & 0.0001 \\
\hline Age2 & $-0.1034^{* * *}$ & 0.0063 & Age2 & $-0.1775^{* * *}$ & 0.0281 \\
\hline Age3 & $-0.0729^{* * *}$ & 0.0068 & Age3 & $-0.156^{* * *}$ & 0.0263 \\
\hline Garage & $0.1126^{* * *}$ & 0.0059 & Garage & $0.1316^{* * *}$ & 0.0344 \\
\hline \multicolumn{6}{|c|}{ Neighborhood attributes } \\
\hline Educational Index & $0.416^{* * *}$ & 0.0225 & Educational Index & $0.9892^{* * *}$ & 0.0939 \\
\hline Entropy Index & $0.2312^{* * *}$ & 0.0234 & Shopping Center & 0.2308 & 0.1518 \\
\hline \multicolumn{6}{|c|}{ Accessibility Attributes } \\
\hline 2MAccess & $0.0916^{* * *}$ & 0.0133 & 2MAccess & $0.2163^{* * *}$ & 0.0466 \\
\hline 1Maccess & $0.0652^{* * *}$ & 0.0084 & 1Maccess & $0.0918^{* *}$ & 0.0357 \\
\hline Network1 & $-0.0732^{* * *}$ & 0.0069 & Network1 & $-0.127^{* * *}$ & 0.036 \\
\hline Network2 & $0.0458^{* * *}$ & 0.0064 & Network2 & $0.1029^{* * *}$ & 0.0302 \\
\hline Network3 & $-0.038^{* * *}$ & 0.006 & & & \\
\hline Sintra & $-0.0614^{* * *}$ & 0.0134 & & & \\
\hline Cascais & $0.1517^{* * *}$ & 0.0259 & & & \\
\hline Pseudo $R^{2}$ & \multicolumn{2}{|c|}{0.795} & Pseudo $R^{2}$ & \multicolumn{2}{|c|}{0.76} \\
\hline LM statistic & \multicolumn{2}{|c|}{$1154.496^{* * *}$} & LM statistic & \multicolumn{2}{|c|}{$19.940^{* * *}$} \\
\hline Log likelihood & \multicolumn{2}{|c|}{236.608} & Log likelihood & \multicolumn{2}{|c|}{-693.486} \\
\hline
\end{tabular}

Note: ${ }^{* * *},{ }^{* *}$, and ${ }^{*}$ denote coefficient significantly different from zero at the $1 \%, 5 \%$, and $10 \%$ level of significance, respectively.

\subsection{Model description}

In order to estimate the market value of the real estate stock and the value capture potential of the Lisbon subway, two simulation procedures were developed: one for the residential market and another for the non-residential market (retail, office, and warehouse). Figure 2 presents the initial data processing and estimate of the attributes of each property simulated in the model for the residential market, while Figure 3 illustrates the structure of the simulation model with all the cycles and processes invoked by the simulation model. A similar structure was adopted for the non-residential market simulation model.

For each iteration, the model generates a synthetic population of residential properties for Lisbon based on the statisti- cal distributions available for the census block using a Monte Carlo simulation procedure. All the structural attributes generated from the statistical census data are considered as independent variables with the exception of area, which depends on the number of bedrooms generated. This simplification assumption significantly reduces the complexity of the interrelation between the different attributes; however it might lead to some unreliable configurations in some low probability cases.

\subsection{Results discussion}

For the current study, 100 iterations for the residential and the non-residential simulation models were used. The summary of the average values obtained from the simulation are presented in Table 4 . The resulting values show that approximately 2.5 


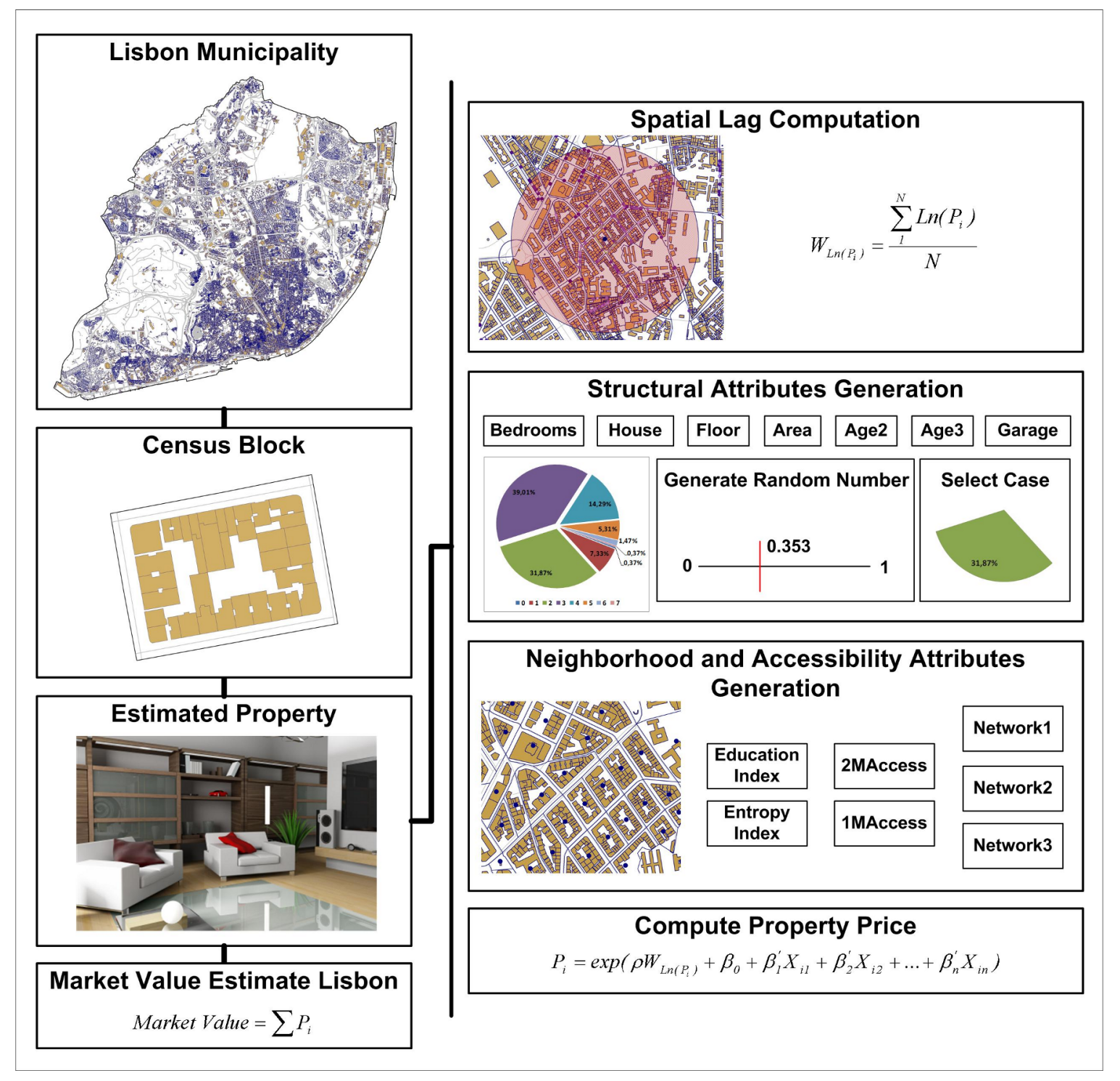

Figure 2: Property attributes generation of the synthetic properties model for market value estimation. 


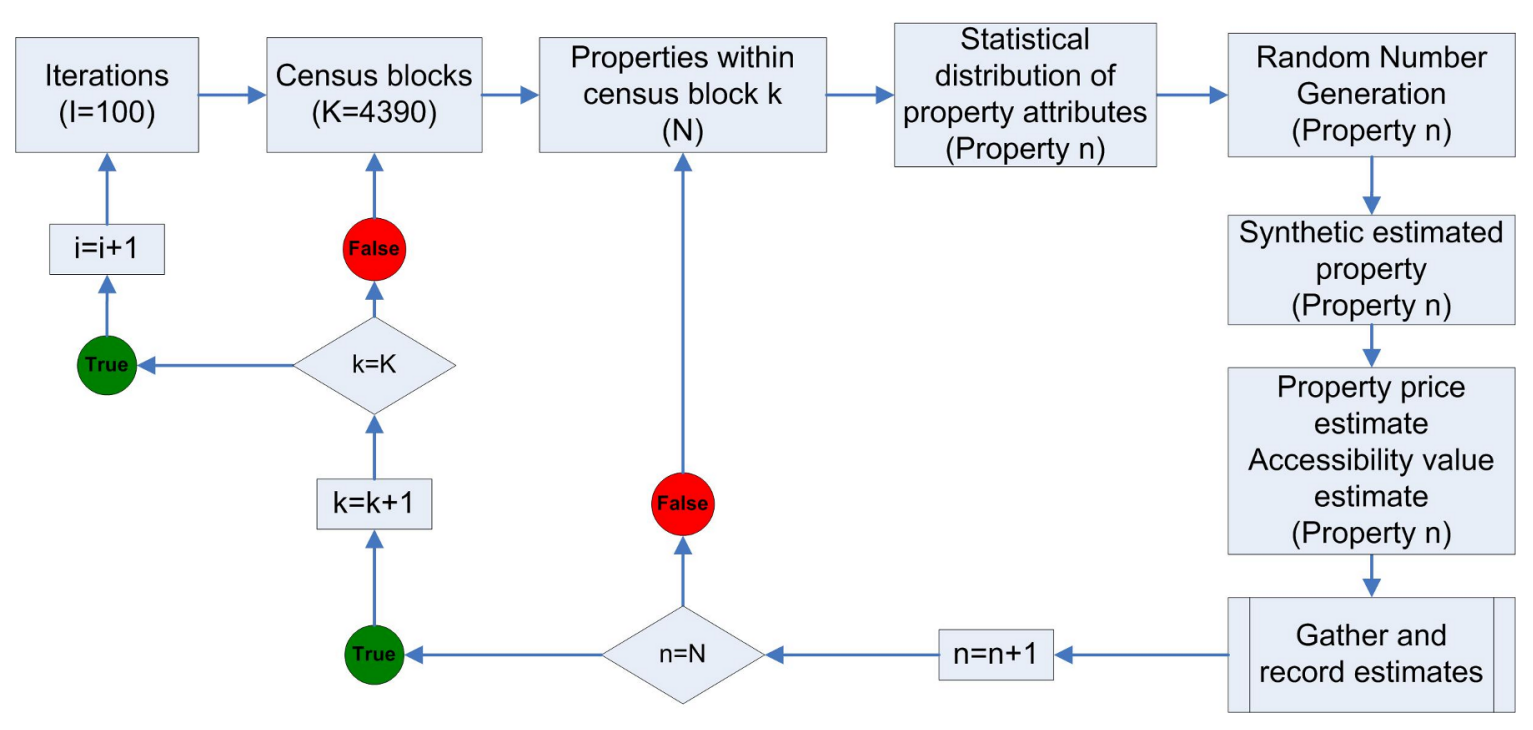

Figure 3: Flowchart of value capture simulation model.

percent of the total residential market value is derived from subway valuation, which is quite significant considering that not all the Lisbon municipality is served by the subway.

The results for the non-residential market show a higher valuation (approximately 9 percent of the total nonresidential market value) which is derived from a higher coefficient for the subway service in the hedonic price model, but also from the higher concentration of activities in the city center where the subway presents a higher concentration of stops.

The total subway valuation obtained for the Lisbon municipality is approximately $€ 2.9$ billion, which would be sufficient at the current prices of Lisbon's subway construction of $40-48$ $\mathrm{km}$ of line (see Table 4). This initial assessment shows the huge potential of value capture from subway that is available for the Lisbon municipality.

Thus, the obtained values are used as a reference for the following taxation estimates, and result in the maximum value that could be taxed to property owners. As we are estimating annual taxation systems, the obtained value results are an upper bound of the cumulative taxing revenue, considering that 20 years at current prices are equivalent to property fruition with property price updates (discount rate of $4.96 \%$ ).

\section{$5 \quad$ Land value tax model}

\subsection{Land value tax code}

Land value taxation in Portugal was reformed in 2003 with the introduction of the Municipal Tax on Immovable Property (IMI), which merges taxes on land and property into a
Table 4: Summary of the results of the value capture potential simulation (all values in millions of euros).

\begin{tabular}{lcc}
\hline & $\begin{array}{c}\text { Residential } \\
\text { uses }\end{array}$ & $\begin{array}{c}\text { Retail, office and } \\
\text { warehouse uses }\end{array}$ \\
\hline Total market value & 61431 & 148 \\
Total subway valuation & 1512 & 13 \\
Total Network1 valuation & -1183 & -3 \\
Total Network2 valuation & 1124 & 7 \\
Total Network3 valuation & -701 & \\
Total Sintra valuation & -65 & \\
Total Cascais valuation & 46 & \\
\hline
\end{tabular}

single tax that is applied to buildings, improvements, and personal property rather than land value, being closer to a real estate taxation principle.

Although this tax is not fully a land value capture mechanism, due to the incorporation of physical features of the property in its specification, this legislation will be used as base to develop the value capture simulation model for the municipality of Lisbon,.

The IMI tax is calculated as a tax rate that is applied to the estimated real estate value of a property. This tax rate must be set by each municipality and should range between 0.2 and 0.5 percent $(0.5 \%$ in the case of the Lisbon municipality). The real estate value is computed using a reference equation defined as:

$$
V_{t}=V_{c} \times A \times C_{a} \times C_{l} \times C_{q} \times C_{v}
$$

where $V_{t}$ is the real estate estimated value (asset value), $V_{c}$ is a base construction value per square meter established by 
Table 5: Area function coefficients for IMI calculation.

\begin{tabular}{lc}
\hline Area function & Coef. \\
\hline Retail use & 1.20 \\
Office buildings & 1.10 \\
Dwellings & 1.00 \\
Controlled-cost dwellings & 0.70 \\
Industrial and warehouse uses & 0.60 \\
Retail and office uses in warehouse buildings & 0.80 \\
Covered enclosed parking lots & 0.40 \\
Covered open parking lots & 0.15 \\
Open parking lots & 0.08 \\
Buildings without construction permits & 0.45 \\
Storage facilities & 0.35 \\
\hline
\end{tabular}

Source: Adapted from 2003 Taxation Code.

each municipality ( $€ 615 / \mathrm{m}^{2}$ in the case of the Lisbon municipality), $A$ is the equivalent area of the property in square meters, $C_{a}$ is an area function coefficient, $C_{l}$ is a location coefficient, $C_{q}$ is a quality and comfort coefficient, and $C_{v}$ is an age correction coefficient.

The equivalent area $A$ is a new factor in urban property valuation that aggregates the building construction area and the exceeding area of the parcel not used for construction (see Equation 3).

$$
A=\left(A_{a}+0.3 A_{b}\right) \times C_{j}+0.025 A_{c}+0.005 A_{d}
$$

where $A_{a}$ is the private area (referring to the principal function of the autonomous fraction), $A_{b}$ is the dependent area (e.g., parking space, laundry, animal facility, attic, basement floor), $C_{j}$ is the area adjustment coefficient, $A_{c}$ is the proximity area (vacant land area: limited to two times the construction implantation area), and $A_{d}$ is the distant area (vacant land area: the area exceeding two times the construction implantation area).

The area adjustment coefficient is defined by a table in the tax code, function of the value $A_{a}+0.3 A_{b}$, and the type of use of the property (residential, retail or services, or industrial).

The area function coefficient $C_{a}$ depends on the type of activity the property was developed for, or that is intended for the property following the value presented in Table 5.

The location coefficient $C_{l}$ depends on the type of activity developed (housing, commerce, industry or services) and on the kind of urban property (construction or land for construction) subject to this valuation procedure. The value of this coefficient varies between 0.35 and 3.00, depending in several factors as accessibility (quality and variety), proximity to public facilities (e.g., schools, hospitals, and commerce), public
Table 6: Age correction coefficient for IMI calculation.

\begin{tabular}{lc}
\hline Years since license issuance & Coef. \\
\hline$<2$ & 1.00 \\
$2-8$ & 0.90 \\
$9-15$ & 0.85 \\
$16-25$ & 0.80 \\
$26-40$ & 0.75 \\
$41-50$ & 0.65 \\
$51-60$ & 0.55 \\
$>60$ & 0.40 \\
\hline
\end{tabular}

Source: Adapted from 2003 Taxation Code.

transportation systems, and real estate market value. Yet, this theoretical formulation of this factor is not translated into a any equation and is estimated by a panel of experts.

In theory, this coefficient should be highly correlated with the value capture estimation for each city block previously estimated, due to the inclusion of public transport proximity as one of the main determining factors.

The quality and comfort coefficient $C_{q}$ is a correction factor applied to the value in order to account for increase in value due to improvements and specific quality attributes of a property or decrease in value due to lack of ordinary services (e.g., water and gas supply, and availability of kitchen and bathroom in the property), as presenting parking facilities inside the property or a swimming pool. The value of this coefficient should vary between 0.5 and 1.7 .

The age correction coefficient $C_{v}$ is a function of the number of years since the issuance of the municipal license for use, and takes the following values:

\subsection{Model description}

In order to estimate the land value tax of the Lisbon municipality two simulation procedures were developed (one for the residential market and another for retail, office, and warehouse properties) following the same simulation principles as the market value simulation, using a Monte Carlo simulation and statistical data at the census block level (see Figures 2 and 3).

\subsection{Results discussion}

The simulation was computed with 200 iterations for the residential and non-residential simulation models. A summary of the average values obtained from the simulation is presented in Table 7. The resulting values show that approximately 55 percent of the total asset value (for residential and 
non-residential real estate stock) is derived from the location coefficient, which in theory is linked to proximity to public transport service and facilities.

The observed total asset value of the real estate stock of Lisbon (approximately €23 billion) is considerably smaller than the market value of the stock estimated by the value capture simulation model (approximately $€ 76$ billion). This difference (observed value approximately 30 percent of estimated market value) can be explained by the considerable penalty introduced by the age correction coefficient $C_{v}$, which reduces the value of the considerable portion of Lisbon properties more than 60 years old to 40 percent of their original values.

This degradation of property value due to age (see Table 6), although also observed in the market, does not present as significant elasticity as in the fiscal estimation of the market value. The reason behind this considerable difference is the political decision to reduce the tax burden on building owners of old building, who (under rent control legislation that until recently allowed very low rent prices for old tenants), might not have enough financial resources to maintain their buildings and pay the property ownership taxes at market value prices.

The total annual tax collection estimated would be approximately $€ 113$ million. The amount of tax collected in 2009 by the municipality of Lisbon was $€ 88$ million, which is fairly close to the estimated value; applying the actual 2009 tax rate of 0.4 percent to the simulation model would produce annual estimated tax revenue of $€ 91$ million-a difference of less than three percent. The estimated average tax value per property is $€ 296$ for residential properties and $€ 600$ for non-residential properties.

From the total asset value estimated we can see that approximately 55 percent of the total value of properties is derived from the valuation of the location coefficient $C_{l}$. This fact may indicate that a significant percentage of the value of a property is attributable to the attributes of the surrounding neighborhood, and (particularly considering the definition of this coefficient in the tax code), is strongly influenced by proximity to subway stations.

After this initial assessment and estimation of the current land value tax system, we can conclude that it might be possible to integrate this tax with the value capture of the subway windfalls in order to recoup part of the property value enhancement to finance the subway construction and operation.
Table 7: Summary of the results of the land value tax simulation by land use category (millions of euros).

\begin{tabular}{lrr}
\hline & $\begin{array}{r}\text { Residential } \\
\text { uses }\end{array}$ & $\begin{array}{r}\text { Retail, office } \\
\text { and warehouse } \\
\text { uses }\end{array}$ \\
\hline Total asset value & 17372 & 5287 \\
Location coefficient valuation & 9497 & 2989 \\
Annual tax revenue & 86.861 & 26.437 \\
(rate $=0.5 \%)$ & & \\
\hline
\end{tabular}

\section{Modeling the introduction of an hypothecated tax}

\subsection{Special assessment tax}

In order to model the possible impact of an annual special assessment tax on residential and nonresidential properties around the Lisbon subway, we first mapped the spatial extent of potential value capture areas produced by the simulation model. The results are presented in Figure 4 for the residential market and Figure 5 for the non-residential market. These figures identify the areas where a special assessment tied to subway accessibility could be applied, considering a minimum direct effect of 1 percent of the total market value for each census block.

In the special assessment district, comprising all the areas identified in Figures 4 and 5, the amount charged to each property is not fixed, but is based on market value estimates from the hedonic price model. The subway should recoup only twothirds of the total value derived from proximity to the subway, in order distribute part of the increase in property values to the private sector, as in other planning gain tariffs policies (e.g., the Socially Justified Land Use tariff in Munich) (Hass-Klau 2006). The set target of two-thirds of the total estimated subway proximity valuation is the maximum amount that should be paid during the regular fruition period of a property in the study area, which is normally more than 20 years.

In order to define a percentage of annual tax from the potential value capture estimated, a database of historical real estate prices per square meter was consulted to observe the growth tendency of the real estate market relative to the inflation variation. This historical database from the company Confidencial Imobiliário ${ }^{1}$ shows a strong growth rate for mar-

\footnotetext{
${ }^{1}$ Monthly database that collects the average asking prices of properties in Portuguese cities since 1988. This data is used to compute a real estate market index used by OECD for price Purchasing power parity index for Portugal.
} 
ket prices from 1988 to 2004 (4.06 percent on average), which is considerably higher than the inflation rates from the same period. However, in recent years this tendency of high growth of the real estate prices in the municipality of Lisbon has been stabilizing, presenting average values over the five last years of 3.4 percent per year. The inflation rate for the same period was approximately 2.5 percent according to Statistics of Portugal data, which reveals a net annual growth of approximately 0.9 percent in real estate prices.

The annual charge to property owners at this rate, applied to two-thirds of the estimated subway valuation, will mainly tax that portion of the expected annual increase in property value that is derived from proximity to the subway, and not the capital value of the property ensuring that property owners retain a significant share of the value of subway proximity.

Using this information, we will consider for our analysis a time horizon of 20 years for property fruition, which will translate the subway valuation for the next owner and a yearly update of 0.90 percent growth of the real estate market over the inflation rate.

The total annual special assessment tax for the Lisbon municipality according to these calculations would be $€ 17.078$ million ( $€ 25.617$ million if the tax were assessed against the full value of subway proximity instead of two-thirds of the value). Given the current cost of subway construction in Lisbon, this annual revenue would be sufficient to finance $285 \mathrm{~m}$ of new subway line per year (approximately 36 percent of the current average yearly total), or to pay 24 percent of the annual operational deficit of the subway (based on 2007 operational deficit values).

The estimated tax revenue would have a significant impact on the cost coverage of the subway and enhance the subway network development with a new annual stream of financial resources.

The problem of this taxation policy lies in the increase of the tax burden on property owners without a readily perceptible improvement in public transport service or amenities close to the property location. Apart from the improvement of service in other locations, which may extend the public transport network and improve general accessibility, it is hard for the taxpayer to link the service improvement with the significant increase in taxation. Several studies have found that a tax increase not linked with an improvement in urban amenities and services can lead to lower property values and welfare losses in the medium and long terms (Oates 1969, 1973).

This tax increase would lead to an average increase in the tax burden of 16.62 percent on residential properties and 22.03 percent on non-residential properties. This value represents an average tax increment of $€ 18$ for residential properties and $€ 59$ for nonresidential properties. The spatial distribution of the combined tax burden increase (residential and nonresidential) is presented in Figure 6.

The obtained results suggest that this increase would be more significant for the nonresidential sector, especially for properties located in the city center and around some high activity poles inside Lisbon (see Figure 6). This could lead to a considerable relocation of activities by firms that want to reduce their costs, and could affect the distribution of jobs within the municipality and even the Lisbon metropolitan area. From a transport and land use planning perspective, this could generate significant imbalances, creating relocations to less accessibility in public transport areas that may affect overall regional sustainability. The effects of this imbalance should be carefully analyzed prior to the implementation of this type of policy, but these issues are beyond the scope of this paper.

\subsection{Integration of subway value capture with current land value tax}

The integration of the existing land value tax and the subway value capture mechanism could be performed considering two hypotheses:

- The value capture subway tax would result in an added charge to the current land value tax, using the same tax rate, which would increase the tax burden of all property owners located close to subway stations;

- Or, consider that the actual land value capture tax already includes the subway property valuation and the value capture to finance the subway should be obtained from the current tax collection.

The first option, although capable of generating larger tax revenues to finance the subway construction and operation, leads to an increase of the tax burden to property owners without any improvement of the current public transport service or amenities close to the property location as discussed above.

Nevertheless, we have estimated the value of this tax increment to the current land value tax, considering once again that only two-thirds of the subway uplift in property prices would be taxed and that the tax rate would be the same as the current land value tax. The annual total tax increment for the entire municipality of Lisbon would be $€ 9.542 \mathrm{mil}-$ lion ( $€ 14.313$ million if instead of two-thirds it would be completely charged). This annual value would be sufficient at the current price of Lisbon's subway construction cost of building 


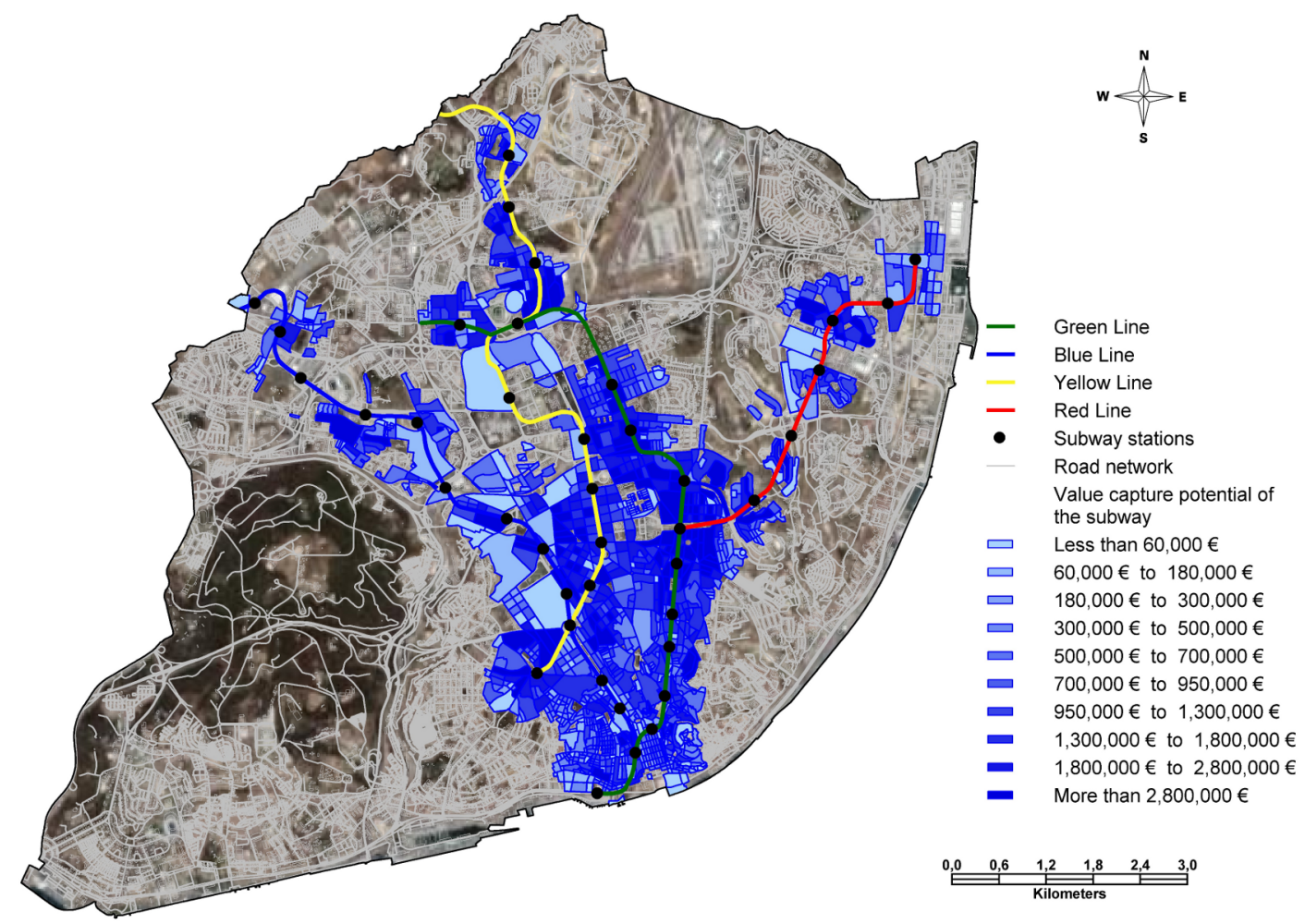

Figure 4: Residential market value capture potential map.

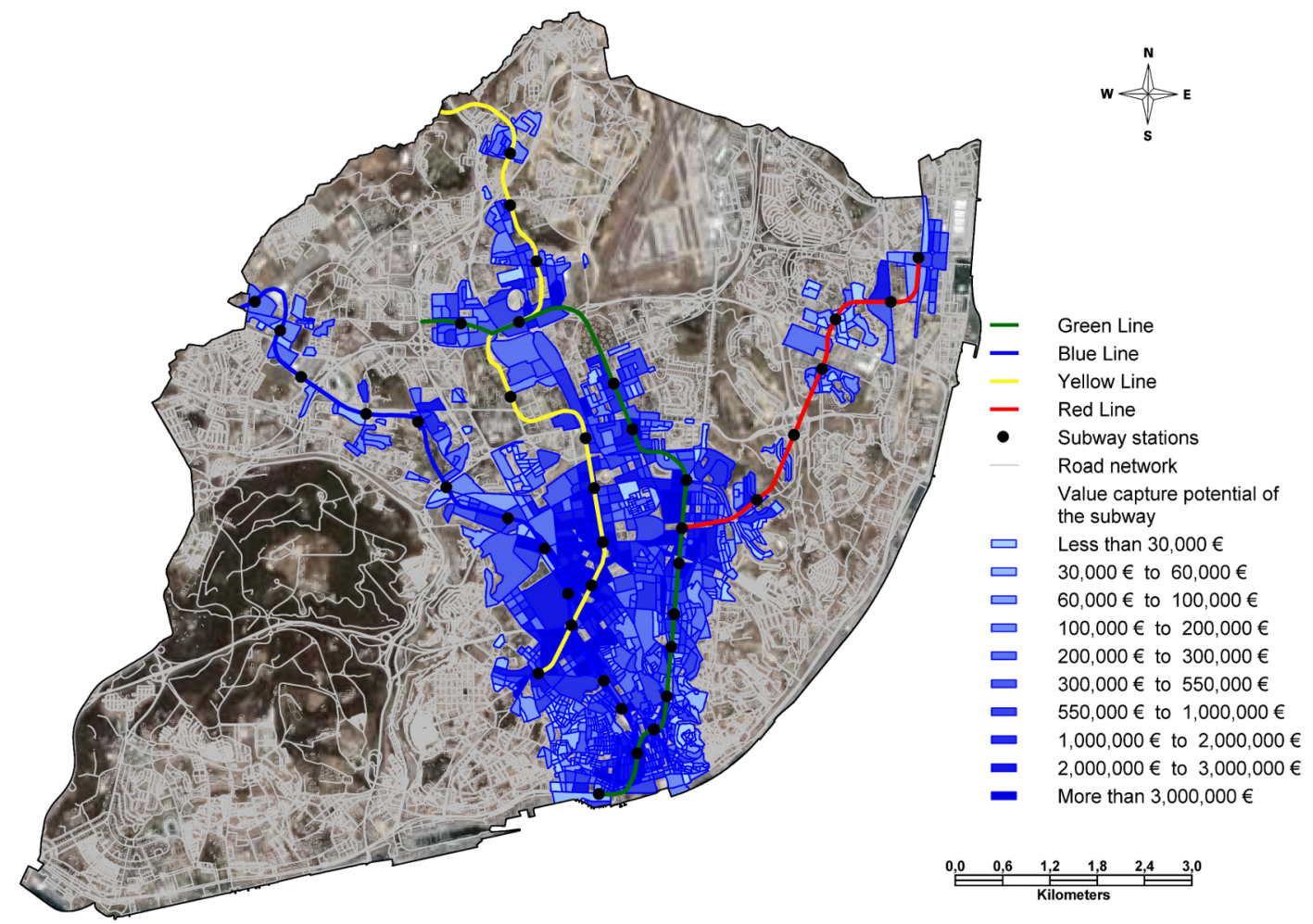

Figure 5: Non-residential market value capture potential map. 
$159 \mathrm{~m}$ of subway line per year (the current average construction pace of the subway is $800 \mathrm{~m}$ per year), or to pay 14 percent of the annual operational deficit of the subway (2007 subway operational deficit values).

Although the value capture revenue estimated might be insufficient to cover the entire annual costs of the subway, it might help to reduce the gap between operational costs and revenues and boost the enlargement of the subway network within the Lisbon municipality and also to the surrounding municipalities.

This tax increment would lead to an average tax burden increase for residential properties of 6.19 percent and 12.35 percent for non-residential properties. This value represents an average tax increment of $48 €$ for residential properties and $105 €$ for non-residential properties. The spatial distribution of the combined tax burden increase is presented in Figure 7 , where the city center and some high activity density poles inside Lisbon are again the main tax burden increase targets, which could lead to the same relocation problems discussed above.

The second option of integration of the subway value capture with the current land value tax is the consideration that the current tax already contains the premium of proximity to the subway stations. This approach encloses a tax revenue reassignment of part of the land value tax from the municipality budget to the subway operation company, Metropolitano de Lisboa.

The transfer of part of the land value tax revenues to the subway company would lead in this case to a political blind alley because the subway is controlled directly by the central government and its funds are assigned directly from the general national taxation system. The link between the local authority and this state owned company is negligible, which would complicate its application and raise issues about the local financing system.

However, we have estimated the value from the general taxation system that should be transferred to the subway operation company in case of application of this policy. This value is computed considering that the relation between market value of a property and the subway value capture potential remain unaltered with the taxation asset value of a property.

The annual total tax shift from the current land value tax charged by the municipality to the subway operation company would be $€ 4090$ million ( $€ 2.007$ million from the residential sector and $€ 2.007$ million from the non-residential sector). This tax revenue would be sufficient at the current prices of Lisbon's subway construction cost of building $64 \mathrm{~m}$ of subway line per year (approximately 8 percent of the current average construction pace of the subway) or to pay 6 percent of the annual operational deficit of the subway (2007 subway operational deficit values).

The estimated tax revenues to finance the subway with this approach are considerably smaller than the previous (approximately 40 percent). Nevertheless, the application of this policy would lead to some contribution toward the cost of subway development and operation and reduce by only 3 percent the revenues of the municipality, without increasing the tax burden of property owners that could result in the relocation effects previously mentioned.

\subsection{Comparison of the different value capture mechanisms}

In this section we present general comparison of the different value capture mechanisms performance by considering several indicators. These indicators are:

1. The annual tax revenue generated by each of the proposed value capture mechanisms that may be used for financing the subway construction and operation. This indicator can be considered an economic efficiency performance indicator.

2. The percentage of property owners in Lisbon affected by the introduction of each value capture mechanism. This indicator translates the concern of equity and fairness among the municipality property owners. At the same time, this indicator may be considered also as a proxy indicator of social acceptance.

3. The average tax burden introduced by each financing policy (using as a base for the land value tax the market value of properties) that illustrates simultaneously the economic applicability of the mechanism (excess tax burden can raise economic efficiency issues and generate severe economic activity relocation) and the social acceptance of its implementation.

Moreover, we should also be aware of the legal and institutional framework required for the implementation of each policy. There are some analyzed value capture mechanisms that entail complementary legislation (e.g., Transportation Utility Fees) and institutional re-arrangements (e.g., Land Value Tax reassignment of subway value capture component to the subway operator).

Assessing the different indicators in Table 8, we can try to identify the most suitable policy in light of the advantages and disadvantages introduced by different tested policies. 


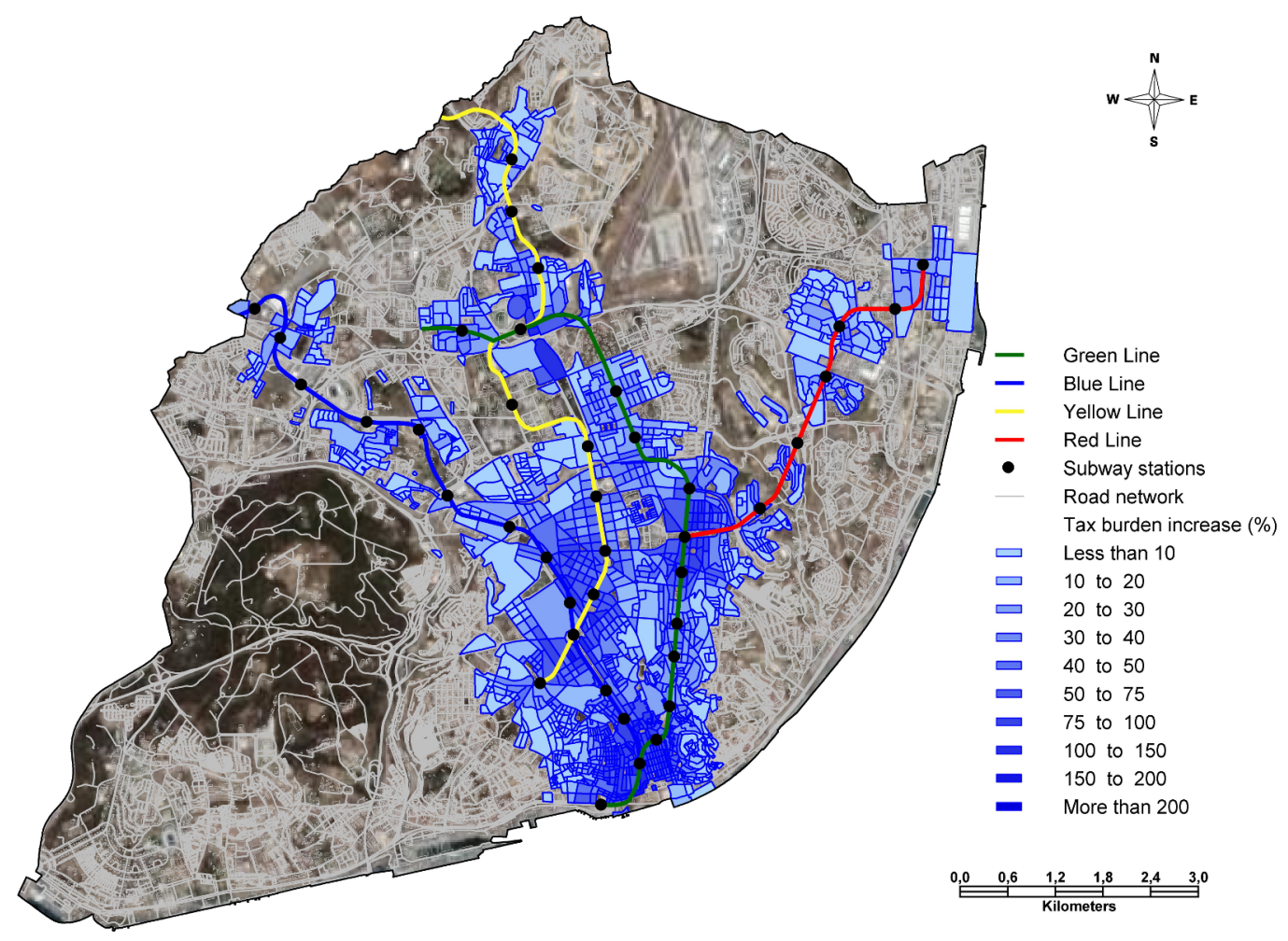

Figure 6: Spatial distribution of the tax burden increase with the Special Assessment tax.

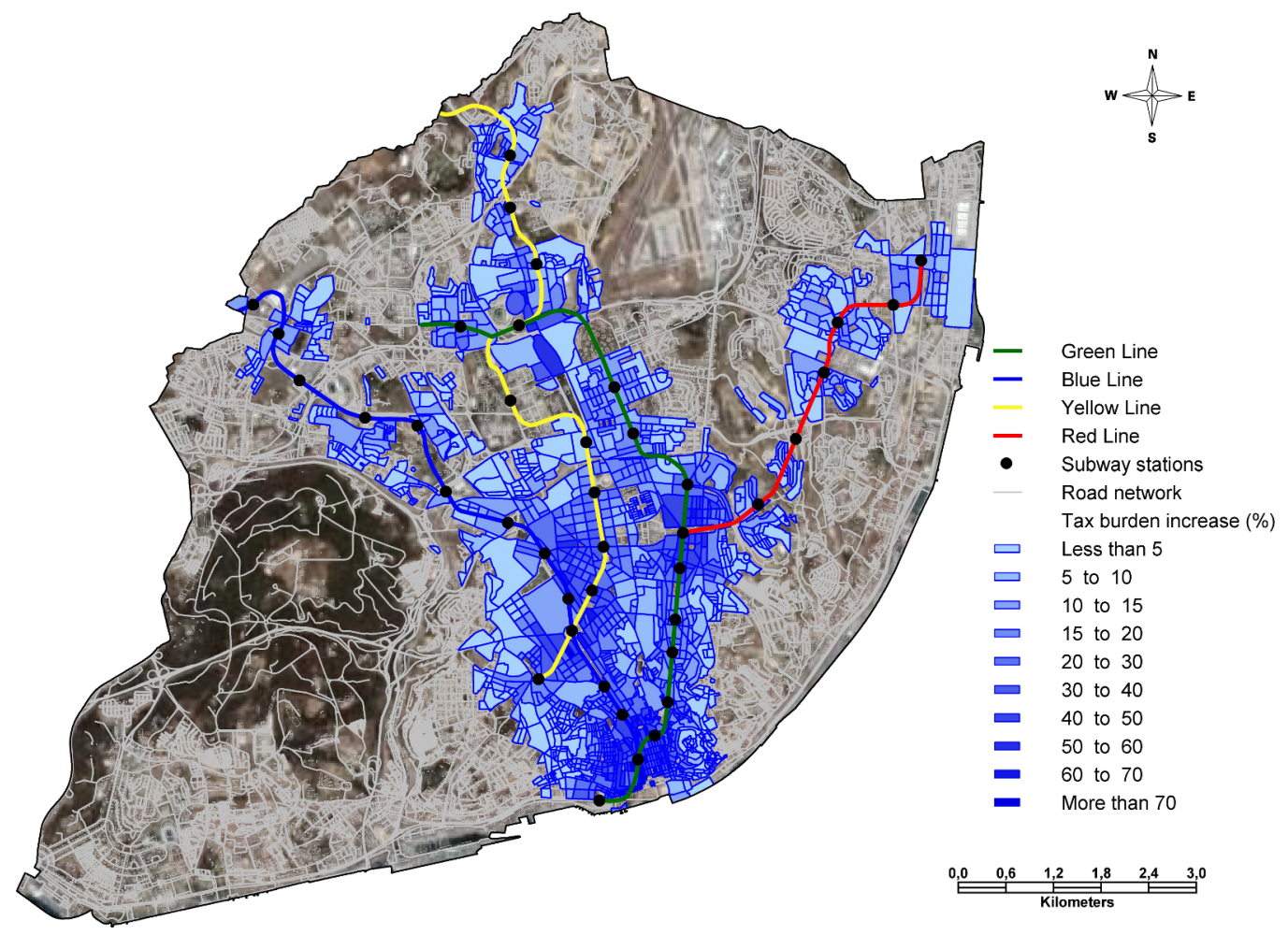

Figure 7: Spatial distribution of the land value tax burden increment. 
Table 8

\begin{tabular}{lcccc}
\hline Value Capture Mechanism & $\begin{array}{c}\text { Annual Tax Revenue } \\
\text { (millions of euros) }\end{array}$ & $\begin{array}{c}\text { Average Residential } \\
\text { Tax Burden } \\
\text { Increase (\%) }\end{array}$ & $\begin{array}{c}\text { Average Non-residential } \\
\text { Tax Burden } \\
\text { Increase (\%) }\end{array}$ & $\begin{array}{c}\text { \% Property } \\
\text { Owners Impacted }\end{array}$ \\
\hline $\begin{array}{l}\text { Special Assessment Tax } \\
\begin{array}{l}\text { Land Value Tax } \\
\text { (Additional Subway Component) }\end{array}\end{array}$ & 17.078 & 11.08 & 22.03 & 46.20 \\
$\begin{array}{l}\text { Land Value Tax } \\
\text { (Subway Component Re-assignment) }\end{array}$ & 9.542 & 6.19 & 12.35 & 77.05 \\
\hline
\end{tabular}

A first examination of the results shows that the Special Assessment Tax produces higher tax revenues; however, it presents a significant tax burden increase, especially for the non-residential sector. The Land Value Tax with an additional subway value capture component may also raise a significant level of tax revenue with a smaller tax burden split among more taxpayers.

The obtained results also indicate that the value capture mechanisms that introduce higher annual tax collection per average increase in tax burden are the Land Value (Subway Component Re-assignment), which does not present any tax burden increase to the property owners, and the Land Value Tax (Additional Subway Component) with a tax collection of $€ 1,542$ million for each 1 percent increase in tax burden. If we use this tax efficiency indicator as the main selection criterion, we might conclude that these two value capture measures are the most suitable for the local context of Lisbon.

\section{Conclusions}

This paper presents an assessment of the land value capture potential of the Lisbon subway, and estimates the financial outcome of the creation of a value capture tax in the municipality of Lisbon and the possible integration of the subway real estate windfalls in the current land value taxation system.

A Monte Carlo simulation procedure is used to estimate the market composition of the residential, retail, and office sectors from aggregated census data at the city block level. This information is used to produce an estimate of the value capture potential of the subway in the Lisbon municipality, based on spatial hedonic pricing models developed in previous research to estimate the extent to which access to transportation infrastructure currently is capitalized into property prices.

The potential value capture estimate is then used to model some different configurations of value capture mechanism to fund the subway operation and expansion through annual taxes to property owners. The integration of a value capture mechanism with current land value tax legislation is also tested under two possible configurations: the creation of an additional subway value capture component to the current tax, or the consideration that the current tax does already contain this component and this value should be reassigned to the subway operator company.

The results obtained show that these value capture policies could significantly increase the pace of subway network construction and reduce the operational deficit of the subway company. Nevertheless, tax burden issues could emerge, leading to the relocation of residences and firms within the Lisbon municipality, or even at the metropolitan scale. The comparative analysis suggests that Land Value (Subway Component Re-assignment) and the Land Value Tax (Additional Subway Component) might be the most suitable options for the Lisbon context.

\section{References}

Benjamin, J. D. and G. S. Sirmans. 1996. Mass transportation, apartment rent and property values. Journal of Real Estate Research, 12(1):1-8. URL http://aux.zicklin.baruch.cuny. edu/jrer/papers/abstract/past/av12n01/v12n1a01.htm.

Berry, J. and L. Sims. 1999. North American examples of innovative funding for public transport.

Cervero, R. and B. Susantono. $1999 . \quad$ Rent capitalization and transportation infrastructure development in Jakarta. Review of Urban \& Regional Development Studies, 11(1):11-23. doi: 10.1111/1467-940X.00002.

Cheshire, P. and S. Sheppard. 2003. Capitalised in the housing market or how we pay for free schools: The impact of supply constraints and uncertainty. In Royal Geographical Society Meeting.

Doherty, M. 2004. Funding public transport development through land value capture programs. Technical report, 
EcoTransit. URL http://www.ecotransit.org.au/ets/node/ 21.

Du, H. and C. Mulley. 2007. The short-term land value impacts of urban rail transit: Quantitative evidence from Sunderland, UK. Land Use Policy, 24(1):223-233. doi: 10.1016/j.landusepol.2005.12.003.

Dueker, K. J. and M. J. Bianco. 1999. Light-rail-transit impacts in Portland: The first ten years. Transportation Research Record, 1685:171-180. doi: 10.3141/1685-22.

Faber, O. 2000. Fair and efficient pricing in transport: The role of charges and taxes. Technical report, European Commission DG TREN.

Glaister, S. and D. J. Graham. 2005. An evaluation of national road user charging in England. Transportation Research Part A: Policy and Practice, 39(7-9):632-650. doi: 10.1016/j.tra.2005.02.013.

Godier, P. 2002. Securing finance for a complex urban rail system. Technical report, London Underground.

GVA Grimley. 2004. Developing a methodology to capture land value uplift around transport facilities. Technical report, Scottish Government. URL http://www.scotland. gov.uk/Publications/2004/11/20385/48339.

Hass-Klau, C. 2006. Capture of land value premiums as a source of funding for public transport: Evidence and practice in selected European metropolitan areas. Technical report, European Metropolitan Transport Authorities (EMTA).

Hass-Klau, C., G. Crampton, and R. Benjari. 2004. Economic impact of light rail: The results of 15 urban areas in France, Germany, UK and North America. Environmental and Transport Planning.

Henneberry, J. 1998. Transport investment and house prices. Journal of Property Valuation and Investment, 16(2):144-158. doi: 10.1108/14635789810212913.

Lari, A., D. Levinson, Z. Zhao, M. Iacono, S. Aultman, K. V. Das, J. Junge, K. Larson, and M. Scharenbroich. 2009. Value capture for transportation finance: Technical research report. Technical Report CTS 09-18, Center for Transportation Studies, University of Minnesota. URL www.cts.umn. edu/Research/Featured/ValueCapture/.

Martínez, L. M. 2010. Financing public transport infrastructure using the value capture concept. Ph.D. thesis, Technical University of Lisbon.

Martínez, L. M. and J. M. Viegas. 2009. Effects of transportation accessibility on residential property values: A hedonic price model in the Lisbon, Portugal, metropolitan area. Transportation Research Record, 2115:127-137. doi: 10.3141/2115-16. URL http://trb.metapress.com/ content/01483765451483nt/.

McGreal, S., J. Berry, G. Lloyd, and J. McCarthy. 2002. Tax-based mechanisms in urban regeneration: Dublin and Chicago models. Urban Studies, 39(10):1819-1831. doi: 10.1080/0042098022000002975.

Nakagawa, D. and R. Matsunaka. 1997. Funding transportsystems: A comparison among developed countries. Pergamon.

Oates, W. E. 1969. Effects of property taxes and local public spending on property values: An empirical study of tax capitalization and the tiebout hypothesis. Journal of Political Economy, 77(6):957-971. doi: 10.1086/259584.

Oates, W. E. 1973. Effects of property taxes and local public spending on property values: A reply and yet further results. Journal of Political Economy, 81(4):1004-1008. doi: 10.1086/260095.

Prest, A. R. 1969. Transport economics in developing countries. Praeger.

Reynolds-Feighan, A., J. Durkan, and J. Durkan. 2000. Comparison of subvention levels for public transport systems in European cities: Final report. Technical report, Department of Public Enterprise. URL http://irserver.ucd.ie/ dspace/handle/10197/124.

Rodriguez, D. A. and F. Targa. 2004. Value of accessibility to Bogota's bus rapid transit system. Transport Reviews, 24(5):587-610. doi: 10.1080/0144164042000195081.

Rodríguez, D. A. and C. H. Mojica. 2007. Capitalization of BRT network effects into land prices. Technical Report Working Paper WP08DR1, Lincoln Institute of Land Policy.

Simon, O. 1999. Briefing: The private finance initiative - an introduction. Technical report, The Institution of Civil Engineers.

Tsukada, S. and C. Kuranami. 1990. Value capture with integrated urban rail and land development: The Japanese experience and its applicability to developing countries. In Seminar M, PTRC Transport and Planning Annual Meeting.

Ubbels, B. and P. Nijkamp. 2002. Unconventional funding of urban public transport. Transportation Research Part D, 7(5):317-329.

Viegas, J. 2005. Organization and financing of public transport.

Vivier, J. 1999. Urban transport pricing. Public Transport International, 48(5):28-35.

Wendell Cox Consultancy. 2006. US public transport expenditures, subsidies \& passenger usage from the 1960s. URL http://www.publicpurpose.com/ut-ussby.htm. 
Whelan, J., Royal Institution of Chartered Surveyors, and Grimley (firm). 2003. Funding London's Transport Needs: A Report. Royal Institution of Chartered Surveyors.

Worsey, S. 2005. Funding Public Transport Infrastructure in the UK: Private Finance and Risk Transfer. Allens Arthur Robinson. 